DOI 10.26886/2414-634X.3(39)2020.3

UDC: 728

\title{
COMPARISON OF THE UKRAINE YOUNG CITIES SLAVUTYCH AND NOVOYAVORIVSK
}

\section{Andrii Duben,}

https://orcid.org/0000-0002-0160-264X

e-mail: andrijduben@gmail.com

Sofiia Bilynska,

https://orcid.org/0000-0002-8159-5012

e-mail: sofiabilynska@gmail.com

Volodymyr Babyak, Assistant,

https://orcid.org/0000-0002-9672-0971

e-mail: volodymyr.babyak@gmail.com

Galyna Gnat, PhD of Architecture, Associate Professor,

https://orcid.org/0000-0003-3459-3636

e-mail: gnatgalyna@gmail.com

Lviv Polytechnic National University, Ukraine, Lviv

The purpose is to study and analyze the youngest cities in Ukraine and compare them. The prerequisites for the emergence of the cities of Novoyavorivsk and Slavutych were studied. The factors that influenced the choice of construction site were identified. The nature of development and prospects for further development of cities have been determined. The features of urban development of both cities were studied. Population density analysis is conducted and age characteristics are given. The results of the comparison were statements that highlight the problems of urban planning and ways of solving them in the construction of Slavutych and Novoyavorivsk. The scope of the article's results can be architectural practice in the field of urban planning. 
Key words: population density, urban construction, medium storey, prefabricated structures, young city, urban planning.

Дубень А. Я.; Білинська С. Ю.; Баб'як В.І.; кандидат архітектури, доцент Гнат Г. О., Порівняння молодих міст України Славутича і Новояворівська / Національний університет «Львівська політехніка», Україна, Львів

Метою роботи є вивчення та аналіз наймолодших міст України та їх порівняння. Вивчено передумови для виникнення міст Новояворівська та Славутича. Визначено чинники, які впливали на вибір місия для будівництва. Визначено характер забудови, та перспективи подальшого розвитку міст. Вивчено особливості містобудування обидвох міст. Проведено аналітику щільності населення та наведено його вікову характеристику. Результатами порівняння стали твердження, які висвітлюють проблеми містобудування та способи їх вирішення при будівництві Славутича й Новояворівська. Сферою застосування результатів статmі може бути архітектурна практика в галузі проектування містобудівних утворень.

Ключові слова: густота населення, будівництво міст, середня поверховість, збірні конструкції, молоде місто, міське планування, містобудування.

Вступ. Нові міста виникають рідко і нині в Україні молодих міст мало. Саме тому явище заснування нових поселень викликає інтерес та має бути вивченим. Для порівняння обрано наймолодше місто України - Славутич та трохи старший Новояворівськ. Своєю появою вони завдячують активному розвитку промисловості та енергетики. Міста дуже подібні між собою тому це порівняння покликане знайти 
відмінності між ними, та зробити висновки, які будуть корисними у створенні нових житлових комплексів.

Коротка історія. Новояворівськ заснований у 1965 р. як поселення для робітників підприємства з видобутку та збагачення сірки, західніше Львова на 30 кілометрів та на схід від районного центру Яворова на 14 кілометрів[1]. Досить довго Яворівський район був одним 3 найбідніших у Львівській області, проте, відкрите тут

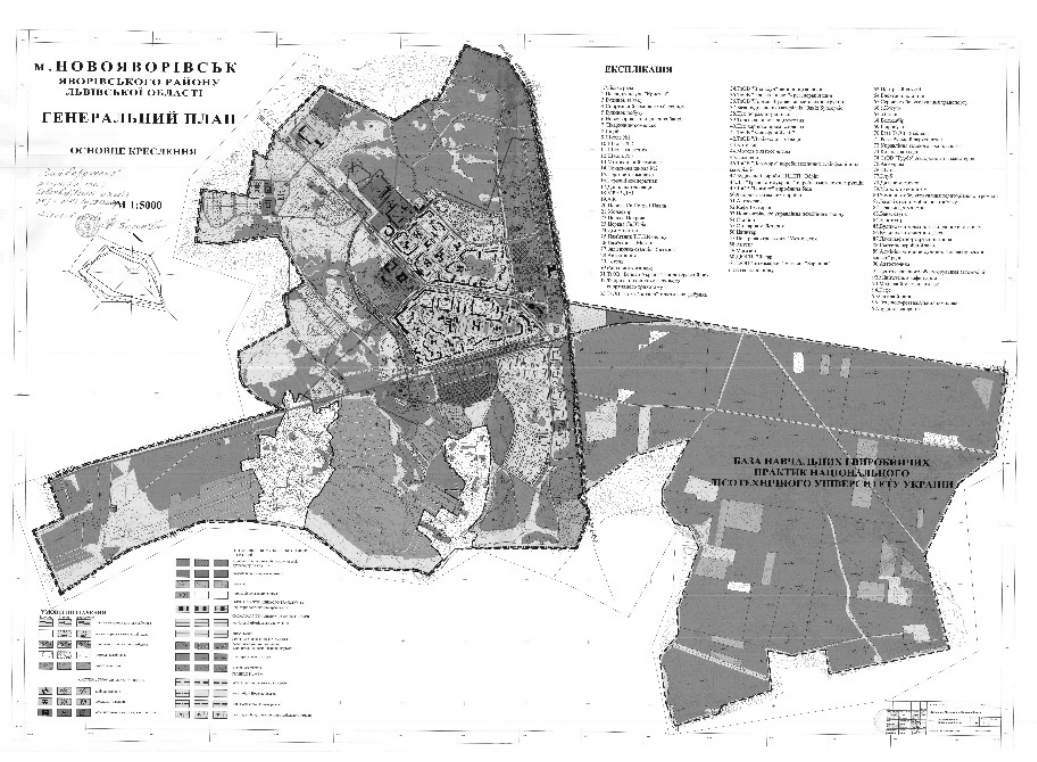

$\begin{array}{lr}\text { хімічне підприємство, } & \text { вринесло в район } \\ \text { інвестиції та, як } & \text { та, } \\ \text { наслідок, поштовх } & \text { розвитку регіону. }\end{array}$

Рис. 1. Генплан Новояворівська[2]

Назва

міста

змінювалась, засноване в 1965 році як селище «Янтарне» (при будівництві знаходили бурштин); перейменоване у 1969 у селище «Новояворівське»; 20 січня 1986 року отримало статус міста «Новояворівське» і 3 червня 2008 року перейменовано у місто «Новояворівськ» [1]. Проте залізнична станція міста і донині має назву «Янтарна».

Внаслідок закладення кар'єру для видобутку сірки відкритим способом люди, що проживали в селах, на його місці були переселені до Новояворівська. Також мешканцями міста стало багато молодих спеціалістів, які були направлені сюди після закінчення навчання на роботу, та залишились тут жити надалі. Особливістю міста є велика густота наслення, яка складає більше 15 тисяч осіб на метр квадратний, для порівняння у Львові ця цифра складає близько 4 тисяч 
осіб на метр квадратний[1]. Це зумовлено середньою поверховістю 5-9 поверхів, проте станом на нині місто обростає приватними садибами і в майбутньому це значення буде коливатись.

Новояворівськ має вигідне розташування поряд із автомобільними та залізничними шляхами, через що відбуваються маятникові міграції частини жителів міста до Львова.

22 квітня 1964 року керівництво хімічної промисловості СРСР та Львівського економічного району видали «КиївНДІП містобудування» завдання на проектування житлового поселення «Сєрний». Спеціалісти розглядали два варіанти розміщення Гірничо-хімічного комбінату відносно сірчаного кар'єру. Перший - західний поблизу Яворова, другий східний, в бік Львова, який в результаті і був реалізований, тому поселення для персоналу підприємства збудували також зі східного боку із санітарно-гігієнієнічною відстанню 5 км біля старої дороги зі Львова, яка зараз закінчується в Новояворівську[1].

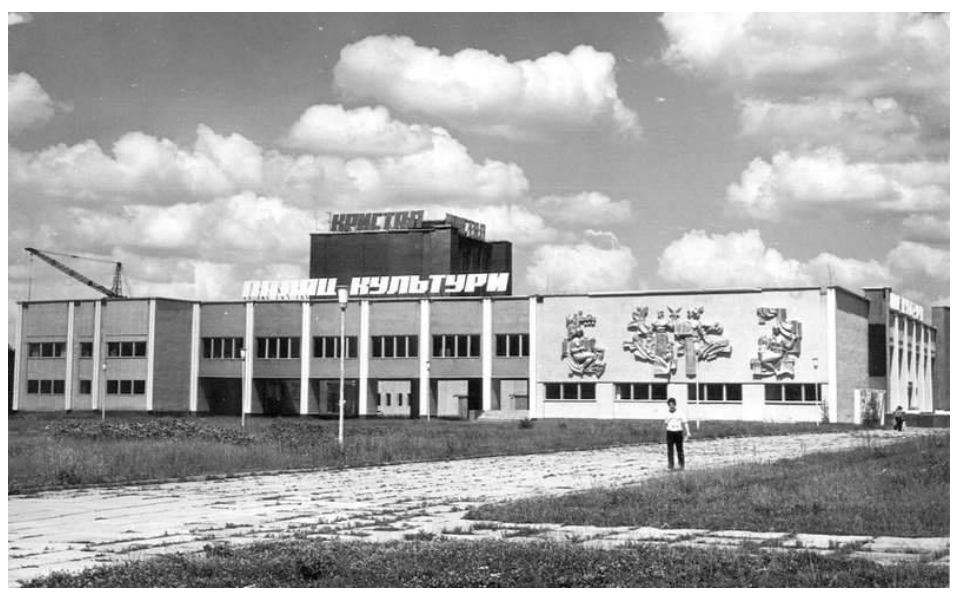

Рис. 2. Палац культури[3]

Масштабні будівельні роботи почались 1970 року, до цього тут проживало 1019 мешканців. Одним з перших були збудовні середня 
школа на 1280 учнів та палац культури із залом на 800 глядачів, та бібліотекою[1].

Будівництво поселення розпочалось із зведення гуртожитків для будівельників самого міста і сірчаного підприємства, які досі експлуатуються та розміщені в центрі міста. 20 січня 1986 селище отримало статус міста. На сьогодні у місті сумарна площа житла 420 тис м2. Середній вік жителя міста 25,2 років.

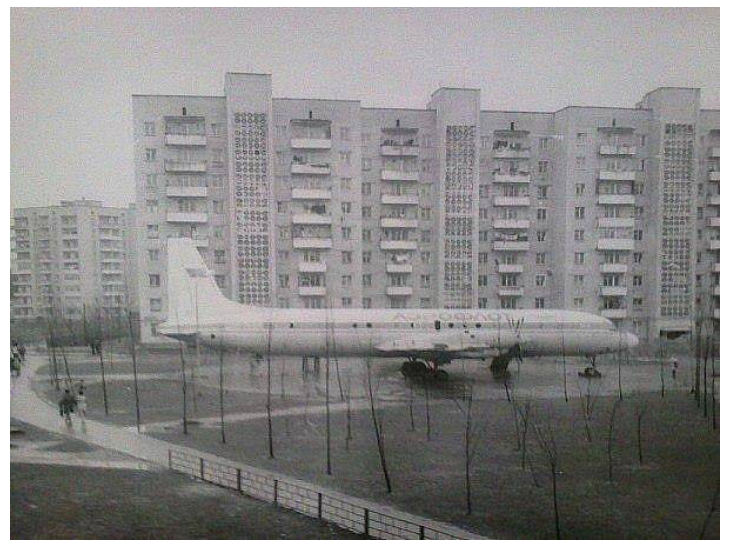

Рис. 3. Літак-кафе[3]

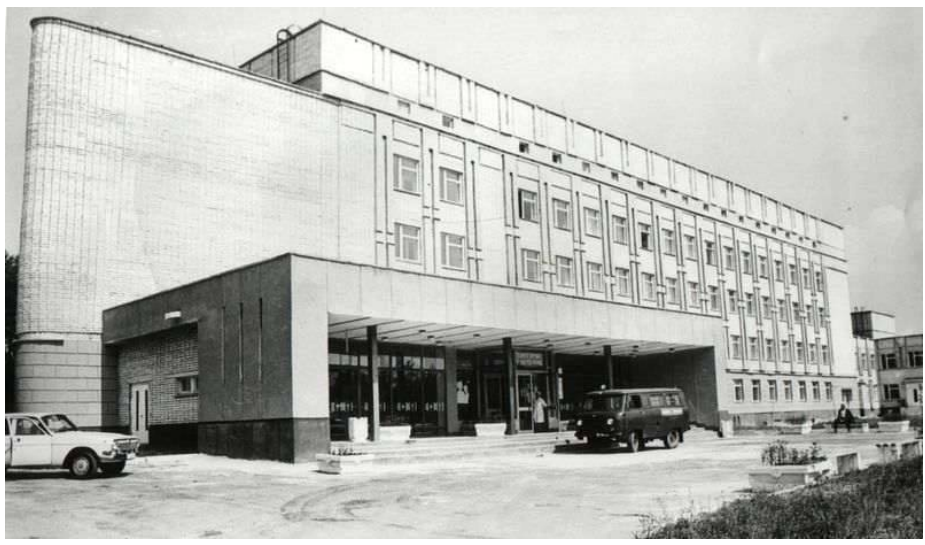

Рис. 4. Лікарня Новояворівська[3]

Славутич. Приводом для зведення міста стала аварія на ЧАЕС. Рішення про будівництво міста було прийнято 2 жовтня 1986 року, а в січні 1987 року почалось будівництво, тому літочислення міста ведеться з 1987 року[4]. В Березні 1988 року були здані в експлуатацію перші квартири. Місто будували дуже швидкими темпами.

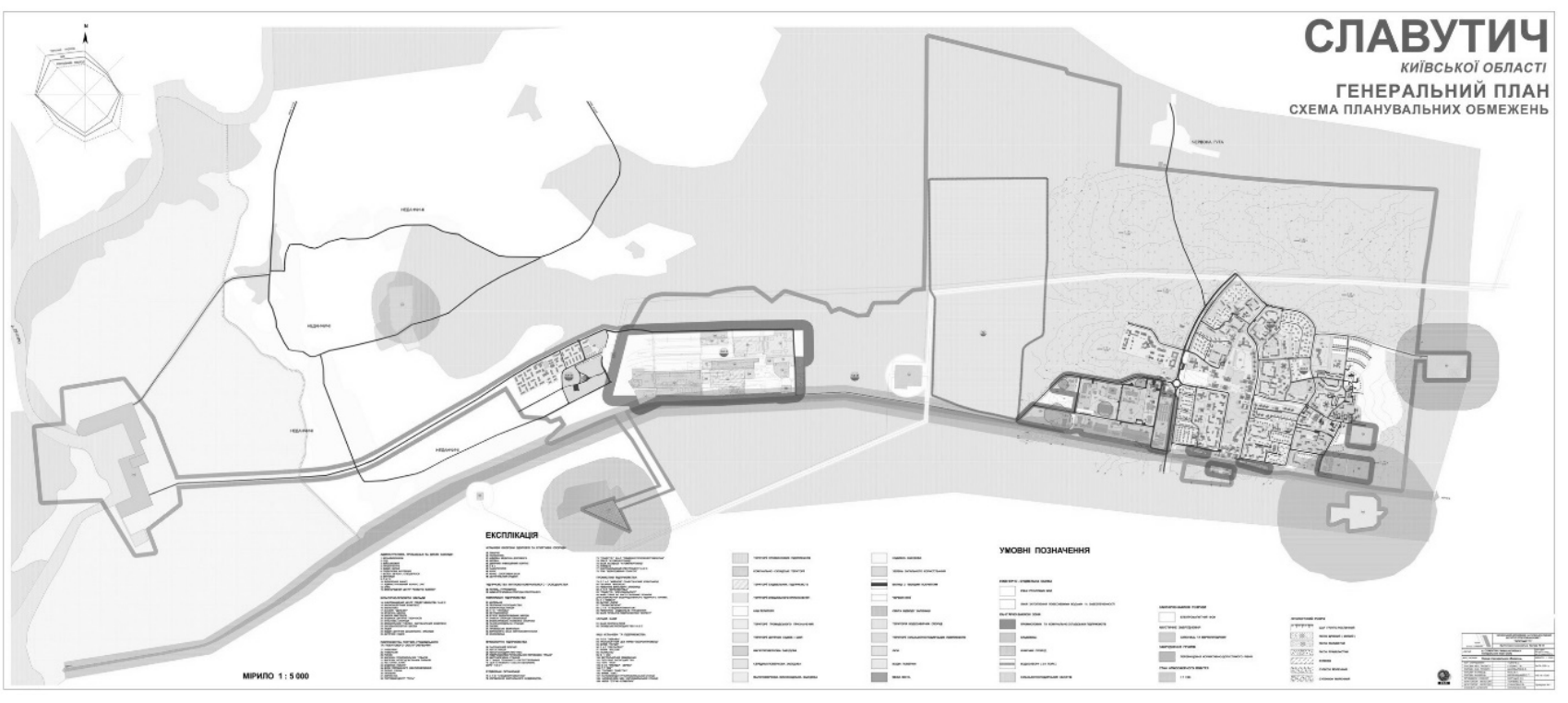




\section{Рис. 4. Генеральний план Славутича[5]}

Ідея збудувати нове місто саме там, де воно $€$ зараз, була затверджена не зразу, спочатку планували побудувати новий мікрорайон у Чернігові або Вишгороді, ця ідея мала плюси у тому, що не потрібно будувати нову інфраструктуру для окремого міста, а скористатись існуючою. Але відстань до Чорнобильської станції, для обслуговування якої було збудоване місто була надто великою, а також доставляти будматеріали було затратно на таку відстань від Дніпра, тому було прийняте рішення збудувати місто на місці станції Нерафа, на відстані 50 кілометрів від АЕС[6].

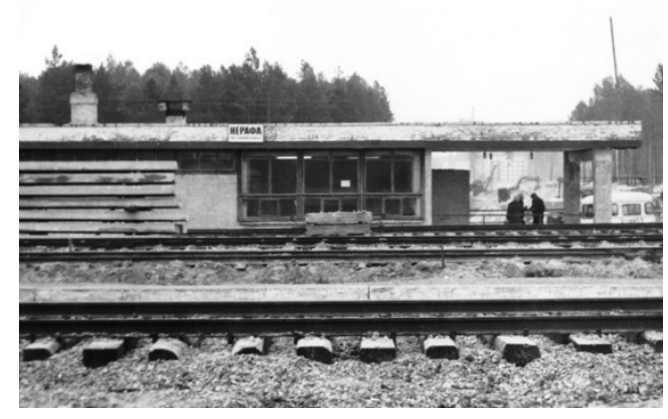

Рис. 5. Станція Нерафа[7]

Будівництво міста відбувалось за проектами архітекторів із восьми країн колишнього СРСР: Литовської, Латвійської, Естонської, Грузинської, Азербайджанської, вірменської, Російської та Української республік. Тому нині місто поділене на тринадцять кварталів:

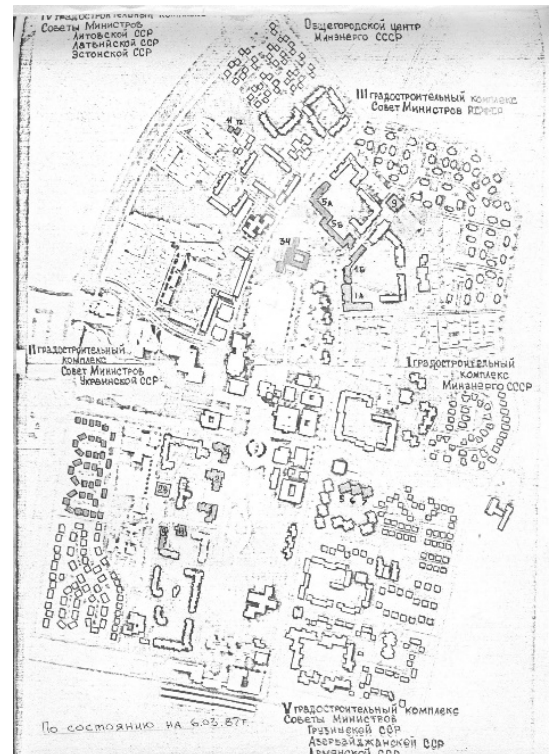
Бакинський, Білгородський, Вільнюський, Добринінський, Єреванський, Київський, Невський, Московський, Печерський, Ризький, Таллінський, Тбіліський та Чернігівський. Територія забудови міста займає 7,5 км2.

Рис. 6. Робочі креслення генплану[7] 
Багато жителів і зараз працюють у зоні відчуження, де проводять роботи пов'язані із зняттям 3 експлуатації, моніторингом науковоюдіяльністью та обслуговуванням зупиненої станції. До зони відчуження ходить потяг із Славутича до ДСП ЧАЕС. Кількість населення міста станом на 2017 рік становила 25096 осіб.

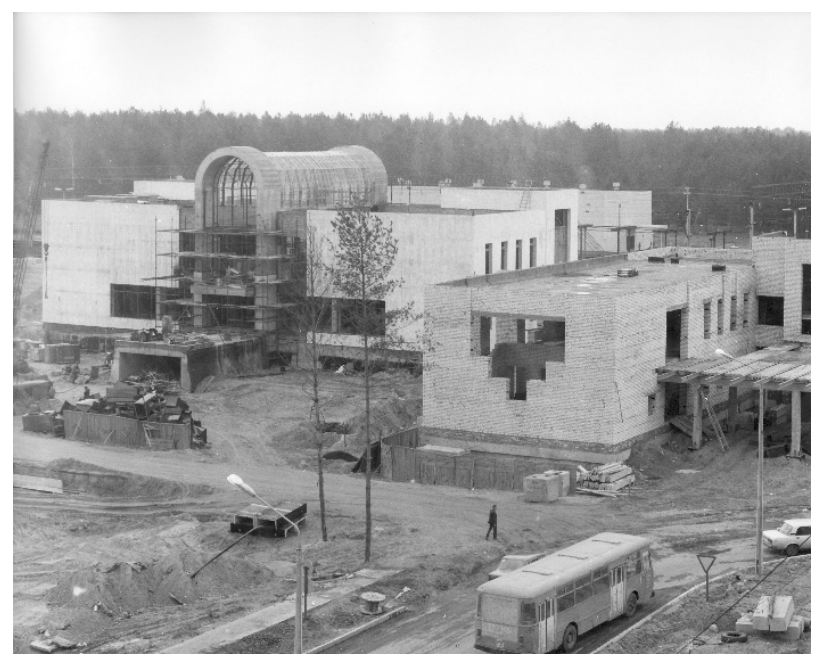

\section{Рис. 7. Залізничний вокзал Славутича[7]}

Організацією, яка займалась проектуванням міста був Київський зональний НДІ типового та експериментального проектування. Головним архітектором проекту був Боровик Федір Ілліч. Під його керівництвом був розроблений генплан, який за розміщенням кварталів наближено асоціюється з розміщенням на карті країн, архітектори яких їх проектували[6].

Одними з ключових фракторів фрормування основних планувальних осей було розміщення залізничної станції, на місці якої збудували вокзал, поряд розташований автовокзал і від цих двох вузлів, перпендикулярно залізниці розміщено вісь на яку нанизано громадські споруди, навколо яких і було збудовано місто.

Архітектори кожної республіки запропонували свої кращі проекти житлових будинків. Будинки у різних кварталах відрізняються не лише планувальними рішеннями, а й зовнішнім виглядом. Наприклад будинки Тбіліського кварталу складали із керамзитобетонних блоків, а фрасад штукатурили особливим типом штукатурки - гажевою, яка характерна для Грузії, тому саму глину привозили з кар'єрів у Грузії. Це був трудомісткий процес, який вимагав більше часу ніж, наприклад, 
зведення будинків за технологіями прибалтійських архітекторів. Їхнє панельне житло вирізнялось високим рівнем готовності та зводилось швидше, порівняно з іншими кварталами. Вірменські будинки були облицьовані рожевим туфом, також привезеним на місце будівництва. Крім особливостей архітектури окремих кварталів, у місті були встановлені скульптури різної тематики[6].

\section{Порівняння}

Спільне. Обидва міста засновані вздовж шляхів - Славутич на місці залізничної станції вздовж залізниці яка веде з Чернігова в Прип'ять, Новояворівськ, на шляху із Львова до Яворова. Так само на місце закладення міст впливали фрактори доступності до підприємств. У технічному завданні на будівництво Славутича була вимога розмістити місто на відстані 50 кілометрів від Чорнобильської AEC, для зручності добирання на роботу жителів міста. Новояворівськ заклали на 5 кілометрів до сходу від сіркопереробного комбінату, з тих самих причин. Тому можемо зробити висновок, що логістика була основним параметром, яким керувались при закладенні міста.

Спільним для обох міст $є$ їх оточення лісом, обидва міста збудовані серед лісів та озер, що є сприятливим для якості життя мешканців фрактором.

Для обох міст характерний високий рівень народжуваності та низький рівень смертності. Середній вік мешканців Славутича - 32 роки, а Новояворівська - 25,2 роки. Такі цифри зумовлені комплексами освітньої інфрраструктури, які притягують молоді сім'ї, припускаю, що нижча цифра Новояворівська зумовлена більшою кількістю населених пунктів поблизу міста, що спричиняє міграцію сюди через кращу інфрраструктуру молодого міста.

Близько 80 відсотків житла Славутича й Новояворівська багатоквартирні будинки, тому для обох міст характерна висока густота 
населення. Для Новояворівська ця цифра складає близько 15 тис осіб на м2.

Відмінне. Унікальність Славутича в тому, що, на відміну від багатьох міст, в тому числі й Новояворівська, проект міста був експериментальним. Особливої уваги заслуговують одразу кілька речей. Велодоріжки у Славутичі були закладені у профрілях вулиць на етапі їх проектування, цього дуже бракує в інших містах. Майже все житло Славутича із збірних елементів, що дозволило його збудувати в такі короткі терміни. У Новояворівсбку цю технологію почали використовувати пізніше, більшість будинків та громадських споруд збудовані із цегли. У Новояворівську не було такого різноманіття типології будинків.

Висновки. Із вікової характеристики обох міст міста можна зробити висновок, що при закладенні нового житла потрібно дотримуватись норм по забезпеченні його освітньою функцією, бо можливість придбати житло найчастіше мають люди працездатного віку, для яких імовірність народження дітей $\epsilon$ високою. Через недотримання цих вимог зараз в Україні у тих містах, в яких відбувається пожвавлення будівництва житла бракує місць у школах та дитсадках. Людський ресурс $є$ дуже важливим, тому забезпечення освітніми та спортивними закладами досліджуваних міст показує, наскільки ці заходи $€$ ефективними методами в омолодженні населення.

Висотність у 5-9 поверхів є оптимальною для комфортного та безпечного життя. Сталий приріст населення та відсутність зменшення його кількості за останні роки у Славутичі та Новояворівську підтверджує цю тезу. Тому при будівництві нового житла слід притримуватись цієї поверховості. У такому випадку не буде 
створюватись надмірне навантаження на мережі міста, а щільність населення буде залишатись високою.

Будівництво із збірних залізобетонних конструкцій житлових будинків $€$ ефрективним засобом зменшення витрат на будівництво, пришвидшення темпів та, після закінчення терміну експлуатації, спрощення демонтажу, та уможливлює їх повторне використання і зменшення будівельних витрат. Ця ідея на нинішній день вважається морально застарілою, але в умовах нестачі житла для незаможних верств населення, молодих сімей, студентів, трудових емігрантів, біженців із районів бойових дій може бути використана як ефрективний засіб вирішення проблеми.

Детальніше вивчення методів проектування Новояворівська, Славутича, та інших міст, збудованих наприкінці 20 століття, може бути корисним для реалізації подібних проектів для сучасних потреб.

\section{תimepamypa:}

1. Світлак І. Янтарне (2012) <https://cutt.ly/XyjliZJ $\geq$

2. Генеральний план міста Новояворівськ (2006) <https://cutt.ly/Syjloct $\geq$

3. Фото України, Яворів, Новояворівськ, Львів. Альбом Старий Новояворівськ (2014) <https://cutt.ly/JyjlycB>

4. Славутицька бібліотека, Наше місто Славутич (2020) <https://cutt.ly/nyjlo8E>

5. Генеральний план міста Славутич (2013) <https://cutt.ly/1yjlafQ>

6. Купний А. (2019) Как строился самый молодой город Украины $<$ https://cutt.ly/wyjlaGG

7. Купний А. Фото Славутича (2020) <https://cutt.ly/dyjlsu1>

\section{References:}

1. Svitlak I. (2012) Yantarne [Yantarne]. Retrieved from https://cutt.ly/XyjliZJ_[in Ukrainian]. 
2. Novoiavorivska miska rada Heneralnyi plan mista Novoiavorivsk (2006) [Master plan of the Novoyavorivsk city]. Retrieved from https://cutt.ly/Syjloct [in Ukrainian].

3. Foto Ukrainy, Yavoriv, Novoiavorivsk, Lviv. Al'bom Staryy Novoyavorivs'k (2014)

[Album: Old Novyavorivsk]. Retrieved from https://cutt.ly/JyjlycB [in Ukrainian].

4. Slavutytska biblioteka, Nashe misto Slavutych (2020) [Our city Slavutich]. Retrieved from https://cutt.ly/nyjlo8E [in Ukrainian].

5. Slavutytska miska rada, Heneral'nyy plan mista Slavutych (2013) [Our city Slavutich]. Retrieved from https://cutt.ly/1yjlafQ [in Ukrainian].

6. Kupniy A. (2019) Kak stroilsya samyy molodoy gorod Ukrainy [How the youngest city of Ukraine was built]. Retrieved from https://cutt.ly/wyjlaGG_[in Russian].

7. Kupnyy A. (2020) Foto Slavutycha [Photos of Slavutich]. Retrieved from https://cutt.ly/dyjlsu1

Citation: Andrii Duben, Sofiia Bilynska, Volodymyr Babyak, Galyna Gnat (2020). COMPARISON OF THE UKRAINE YOUNG CITIES SLAVUTYCH AND NOVOYAVORIVSK. Innovative Solutions in Modern Science. 3(39). doi: 10.26886/2414-634X.3(39)2020.3

Copyright: Andrii Duben, Sofiia Bilynska, Volodymyr Babyak, Galyna Gnat $\odot$. 2020. This is an openaccess article distributed under the terms of the Creative Commons Attribution License (CC BY). The use, distribution or reproduction in other forums is permitted, provided the original author(s) or licensor are credited and that the original publication in this journal is cited, in accordance with accepted academic practice. No use, distribution or reproduction is permitted which does not comply with these terms. 